\title{
Hypothalamic and myocardial lesions after subarachnoid haemorrhage
}

\author{
R. DOSH I A N D G NEIL-D W Y R
}

From the Departments of Neuropathology and Neurological Surgery, Brook General Hospital, London

SUMMARY The hypothalamus and myocardium of 12 patients who had died after a subarachnoid haemorrhage, and of six patients who had died from other intracranial pathology were examined. Only in the patients who had died from subarachnoid haemorrhage were histological lesions found in both the hypothalamus and myocardium. The possible significance of these findings is discussed with particular reference to the sympathetic nervous system.

Increased and prolonged sympathetic activity in patients after subarachnoid haemorrhage (Tomomatsu et al., 1964; Iliynsky and Astrakhantseva, 1967; Neil-Dwyer et al., 1974) has been strongly linked with a variety of electrocardiographic (ECG) abnormalities occurring in this disorder (Cruickshank et al., 1974). Although there is substantial indirect evidence to support this statement, direct evidence is scanty. Myocardial lesions associated with a subarachnoid haemorrhage have been well documented (Conor, 1969), and similar lesions have been produced in animals either by stimulation of the hypothalamus (Melville et al., 1963; Zavodskaya et al., 1972), or with the parenteral administration of catecholamines (Reichenbach and Benditt, 1970).

Hypothalamic damage in patients after subarachnoid haemorrhage has been well described (Crompton, 1963; Smith, 1963) while a variety of animal experimental work has shown that abnormal hypothalamic function can lead to myocardial damage and cardiovascular disturbances (Melville et al., 1963; Greenhoot and Reichenbach, 1969; Zavodskaya et al., 1972). As yet there has been no clinicopathological study establishing whether there is a correlation between hypothalamic and myocardial lesions occurring in subarachnoid haemorrhage, a requisite if the pathophysiology of this condition is to be understood.

Address for correspondence and reprint requests: Dr R. Doshi, Department of Neuropathology, Brook General Hospital, Shooters Hill Road, London SE18 4LW, England.

Accepted 24 March 1977

\section{Patients and methods}

All patients were admitted into the Neurosurgical Unit at the Brook General Hospital between January and September 1975. The patients were divided into two groups, group 1 containing 12 patients who had died after a subarachnoid haemorrhage, and group 2, a control group of six patients who died from a variety of causes, all of which produced raised intracranial pressure. The necropsies in group 1 were consecutive.

Of the 12 patients in group 1, eight were female and four male, the age range was 21-66 years, and the clinical details are given in Table 1 ; in group 2 there were four female patients and two male, and the age range was 20-62 years. The majority of patients in the subarachnoid haemorrhage group followed a fairly typical clinical course with a fluctuating but deteriorating level of consciousness, varying blood pressures and pulse rates (Table 1). Electrocardiograms (ECG) were recorded in six cases (Table 1), and in five of these were considered to be abnormal.

Brains and hearts from the 12 cases of subarachnoid haemorrhage and six cases of raised intracranial pressure due to other causes were examined; of the 12 brains in group 1 (Table 2), three showed intraventricular haemorrhage; four brains contained intracerebral haematoma, and in three cases there was a combination of intraventricular haemorrhage and intracerebral haematoma; of the remaining two brains, cerebral infarction was present in one and no abnormality was seen in the other.

Three blocks were taken from each hypothalamus for paraffin sections: (1) at the level of the 


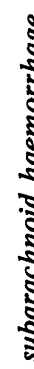

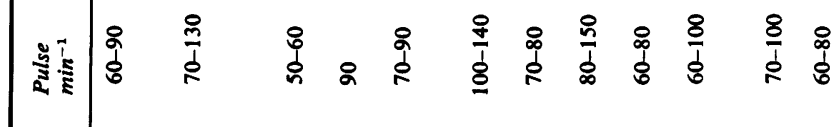
๖े

ษั

)

ํํㄹ 의요

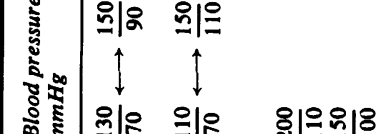

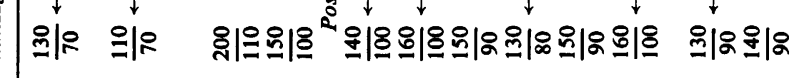

의으윛워 융으 의으 이으<smiles>[AlH2]</smiles>

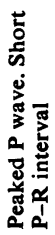
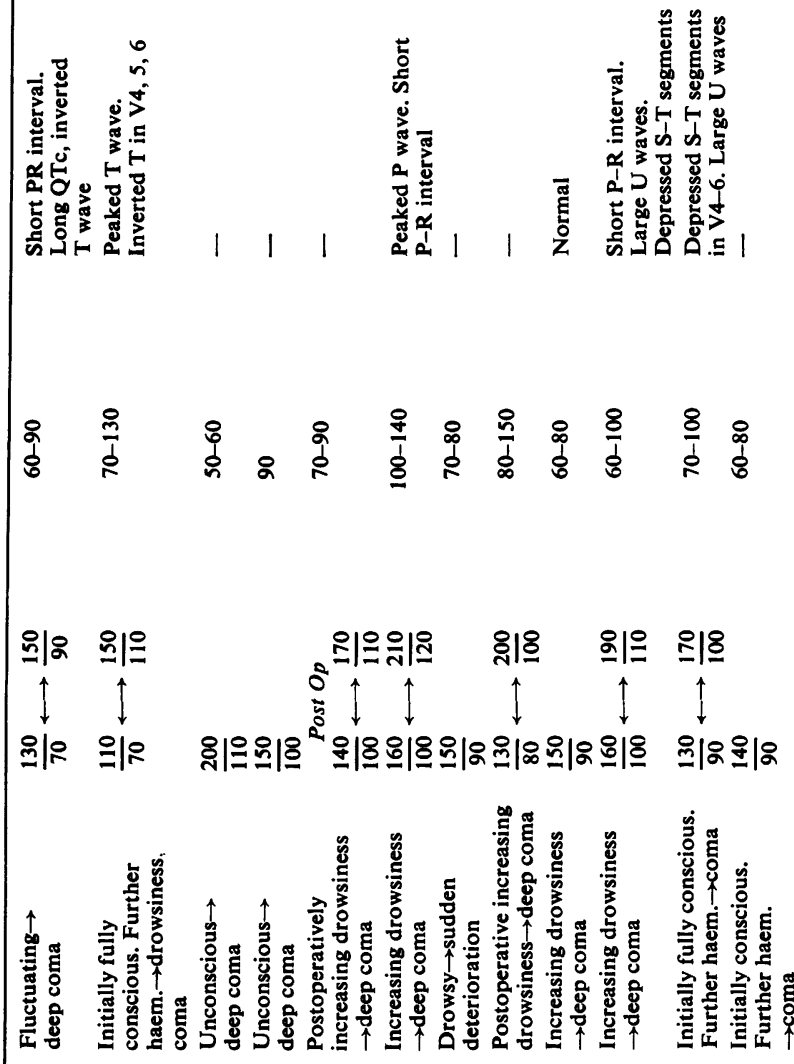

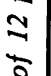

ปั

:

in

จุ๊ิ

:

m

$\approx \vec{\wedge}$

$\infty$

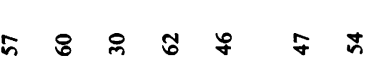

ह

$\cong$

里

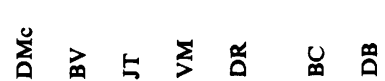


Table 2 Summary of results of postmortem examination of brains and hearts of 12 patients who died after subarachnoid haemorrhage.

\begin{tabular}{|c|c|c|c|c|c|c|}
\hline Name & Site of aneurysm & $\begin{array}{l}\text { Other pathology } \\
\text { in brain }\end{array}$ & Hypothalamus & $\begin{array}{l}\text { Weight of } \\
\text { brain }(g)\end{array}$ & Myocardium & $\begin{array}{l}\text { Evidence of raised } \\
\text { intracranial pressure }\end{array}$ \\
\hline ML & $\begin{array}{l}\text { Anterior } \\
\text { communicating } \\
\text { artery }\end{array}$ & $\begin{array}{l}\text { Haemorrhage in } \\
\text { left basal ganglia } \\
\text { and intraventricular } \\
\text { haemorrhage }\end{array}$ & $\begin{array}{l}\text { Extensive } \\
\text { hypothalmic } \\
\text { infarct }\end{array}$ & 330 & $\begin{array}{l}\text { Focal necrosis of } \\
\text { muscle fibres } \\
\text { with inflammatory } \\
\text { cell infiltration }\end{array}$ & - \\
\hline JS & $\begin{array}{l}\text { Left vertebral } \\
\text { artery }\end{array}$ & $\begin{array}{l}\text { Blood in posterior } \\
\text { horns of lateral } \\
\text { ventricles }\end{array}$ & $\begin{array}{l}\text { Perivascula. } \\
\text { haemorrhage }\end{array}$ & 330 & $\begin{array}{l}\text { Focal necrosis of } \\
\text { muscle fibres } \\
\text { with inflammatory } \\
\text { cell infiltration }\end{array}$ & - \\
\hline MB & $\begin{array}{l}\text { Right internal } \\
\text { carotid artery }\end{array}$ & $\begin{array}{l}\text { Haemorrhage in } \\
\text { right temporal } \\
\text { lobe }\end{array}$ & $\begin{array}{l}\text { Distension of } \\
\text { perforating vessels } \\
\text { and ball } \\
\text { haemorrhages }\end{array}$ & 270 & $\begin{array}{l}\text { Focal necrosis of } \\
\text { muscle fibres } \\
\text { with inflammatory } \\
\text { cell infiltration }\end{array}$ & $+t$ \\
\hline MG & $\begin{array}{l}\text { Arterio-venous } \\
\text { malformation }\end{array}$ & $\begin{array}{l}\text { Haemorrhage in } \\
\text { right frontal } \\
\text { lobe }\end{array}$ & $\begin{array}{l}\text { Perivascular } \\
\text { haemorrhage }\end{array}$ & 300 & $\begin{array}{l}\text { Focal necrosis of } \\
\text { muscle fibres } \\
\text { with inflammatory } \\
\text { cell infiltration }\end{array}$ & ++ \\
\hline DW & $\begin{array}{l}\text { Bifurcation of } \\
\text { both internal } \\
\text { carotid arteries }\end{array}$ & $\begin{array}{l}\text { Haemorrhage in } \\
\text { left temporal lobe } \\
\text { and intraventricular } \\
\text { haemorrhage }\end{array}$ & $\begin{array}{l}\text { Perivascular } \\
\text { haemorrhage }\end{array}$ & 250 & $\begin{array}{l}\text { Necrosis of } \\
\text { individual } \\
\text { muscle fibres }\end{array}$ & + \\
\hline DMc & $\begin{array}{l}\text { Right middle } \\
\text { cerebral artery }\end{array}$ & $\begin{array}{l}\text { Haemorrhage in } \\
\text { right frontotemporal } \\
\text { region }\end{array}$ & $\begin{array}{l}\text { Perivascular cuffing } \\
\text { and microinfarct }\end{array}$ & 560 & $\begin{array}{l}\text { Necrosis of } \\
\text { individual } \\
\text { muscle fibres }\end{array}$ & +++ \\
\hline BV & $\begin{array}{l}\text { Anterior } \\
\text { communicating } \\
\text { artery }\end{array}$ & None & None & 430 & None & + \\
\hline JT & $\begin{array}{l}\text { Right middle } \\
\text { cerebral artery }\end{array}$ & $\begin{array}{l}\text { Infarction in } \\
\text { territory of right } \\
\text { middle cerebral artery }\end{array}$ & $\begin{array}{l}\text { Perivascular cuffing } \\
\text { and microinfarct }\end{array}$ & 275 & $\begin{array}{l}\text { Focal necrosis of } \\
\text { muscle fibres } \\
\text { wilh inflammatory } \\
\text { cell infiltration }\end{array}$ & +++ \\
\hline VM & $\begin{array}{l}\text { Anterior } \\
\text { communicating } \\
\text { artery }\end{array}$ & $\begin{array}{l}\text { Intraventricular } \\
\text { haemorrhage }\end{array}$ & $\begin{array}{l}\text { Perivascular } \\
\text { haemorrhage }\end{array}$ & 380 & $\begin{array}{l}\text { Necrosis of } \\
\text { individual } \\
\text { muscle fibres }\end{array}$ & ++ \\
\hline DR & None & $\begin{array}{l}\text { Haematoma in } \\
\text { left Sylvian } \\
\text { fissure }\end{array}$ & $\begin{array}{l}\text { Distension of } \\
\text { perforating vessels } \\
\text { and ball } \\
\text { haemorrhages }\end{array}$ & 270 & $\begin{array}{l}\text { Necrosis of } \\
\text { individual } \\
\text { muscle fibres }\end{array}$ & ++ \\
\hline $\mathbf{B C}$ & $\begin{array}{l}\text { Right vertebral } \\
\text { artery }\end{array}$ & $\begin{array}{l}\text { Intraventricular } \\
\text { haemorrhage }\end{array}$ & $\begin{array}{l}\text { Perivascular } \\
\text { haemorrhage }\end{array}$ & 390 & $\begin{array}{l}\text { Focal necrosis of } \\
\text { muscle fibres } \\
\text { with inflammatory } \\
\text { cell infiltration }\end{array}$ & + \\
\hline DB & $\begin{array}{l}\text { Left middle } \\
\text { cerebral artery }\end{array}$ & $\begin{array}{l}\text { Haemorrhage in } \\
\text { left temporal lobe } \\
\text { and intraventricular } \\
\text { haemorrhage }\end{array}$ & $\begin{array}{l}\text { Perivascular } \\
\text { haemorrhage }\end{array}$ & 250 & $\begin{array}{l}\text { Necrosis of } \\
\text { individual } \\
\text { muscle fibres }\end{array}$ & + \\
\hline
\end{tabular}

optic chiasm, (2) at the level of the tuber cinerium; and (3) at the level of the mammillary bodies. Blocks from the upper medulla oblongata were taken at two levels. The sections were stained with haematoxylin/eosin ( $\mathrm{H}$ and $\mathrm{E}$ ), haematoxylin/Van Gieson and Luxol fast blue/cresyl violet.

\section{Results}

In the hypothalamus, six of the 12 cases showed small perivascular haemorrhages and oedema of the surrounding tissues in the periventricular region including the paraventricular nucleus and the supraoptic nucleus. It was difficult to assess depletion of neurones but some of the neurones in the paraventricular nucleus were shrunken and atrophic. In two cases there was distension of perforating vessels and vessels with small ball haemorrhages (Fig. 1) similar to those described by Crompton (1963). Another two cases showed marked oedema of the vessel wall involving the endothelial cells with perivascular cuffing by polymorphonuclear leucocytes in the paraventricular nucleus (Fig. 2). Microinfarcts in this region were demonstrated by the presence of fat granule cells and polymorphonuclear leucocytes. One of the cases with severe ECG abnormalities (ML) showed almost complete infarction of the hypothalamus (Fig. 3); in this case small foci of microinfarcts were also present in the thalamus. No hypothalamic lesions were found in one case (Table 2). Sections from the medulla oblongata did not reveal any abnormality. 


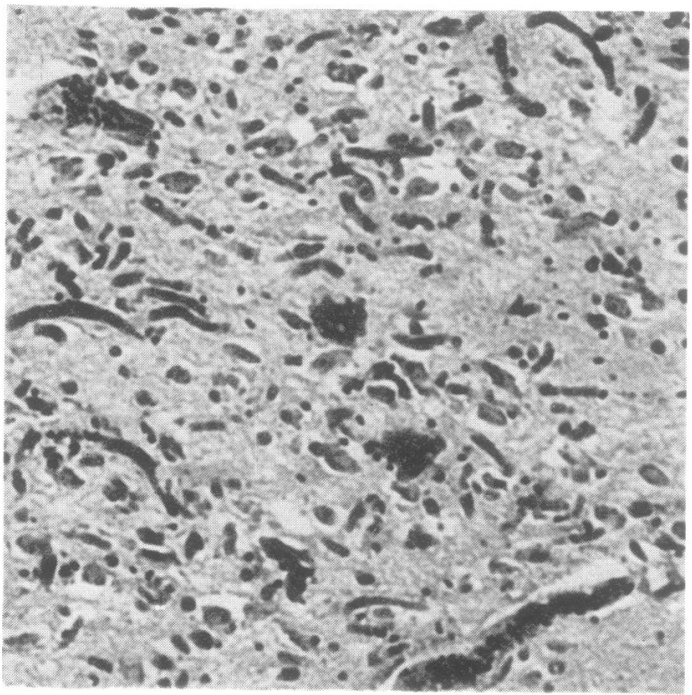

Fig. 1 Distension of perforating vessels with small ball haemorrhages in the paraventricular nucleus. (Haematoxylin and Van Gieson $\times 40$.)

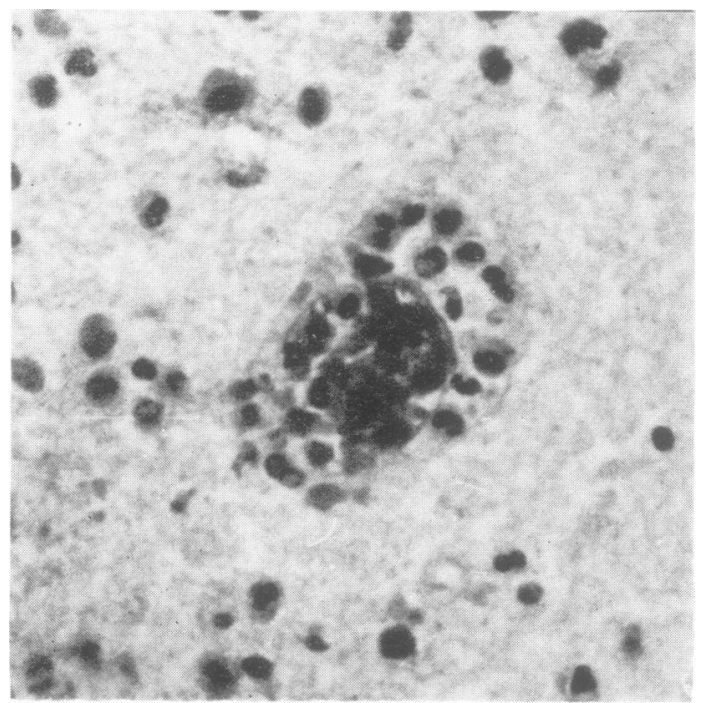

Fig. 2 Perivascular cuffing by polymorphonuclear leucocytes: note fat granule cells in the surrounding brain. (Haematoxylin and Van Gieson $\times 40$.)

\section{CONTROL CASES}

Of the six cases of raised intracranial pressure, three brains contained gliomas, two showed multiple metastases from carcinoma, and a massive subdural abscess was present in one.

Blocks from the hypothalamus and medulla were taken from these brains at the same level as the cases with subarachnoid haemorrhages, and

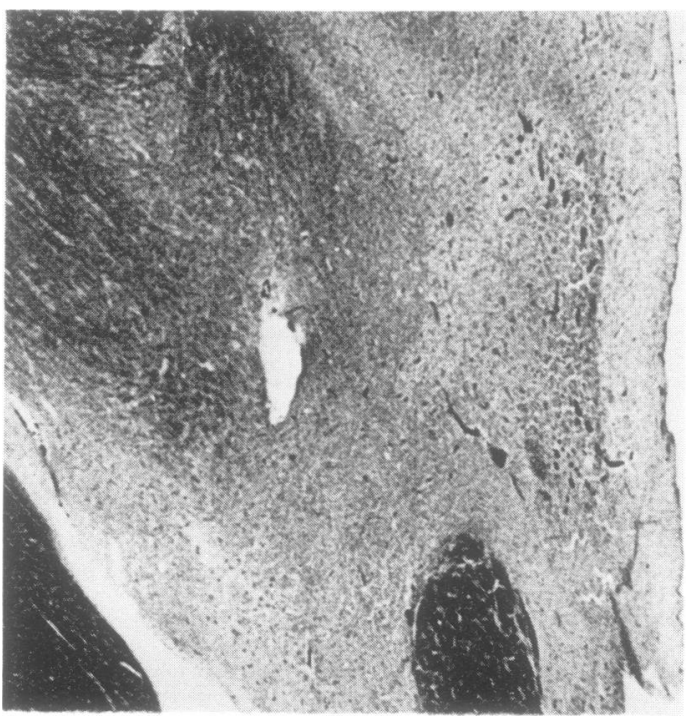

Fig. 3 Pale area in the right lower corner of the hypothalamus is infarcted. (Luxol fast blue and cresyl violet $\times 3.5$.)

the sections were stained by the same techniques. Histologically no abnormality was found in the hypothalamus or in the medulla oblongata in any of these brains.

HEARTS

In a majority of these cases the coronary artery appeared to be normal but there was a moderate degree of atheroma in three cases while in a fourth, severe atheroma was present. Four blocks were taken for paraffin sections from the left ventricle, one from each of the following areas: posterior wall; anterior wall; interventricular septum and apex. The sections were stained with $\mathrm{H}$ and $\mathrm{E}$ and haematoxylin/Van Gieson.

\section{HISTOLOGY}

In six of the group 1 cases there were small areas of necrosis of muscle fibres with interstitial infiltration by polymorphonuclear leucocytes and macrophages (Fig. 4). In five of the remaining six cases the myocardial fibres were distorted and widely separated from each other. In these cases there was necrosis of individual muscle fibres which showed loss of striation, increased eosinophilia, and granular cytoplasm; these necrotic muscle fibres were surrounded by macrophages. In one of these cases along with myofibrillar degeneration there were small areas of subendocardial haemorrhage. Only in one case was no abnormality seen (Table 2). 


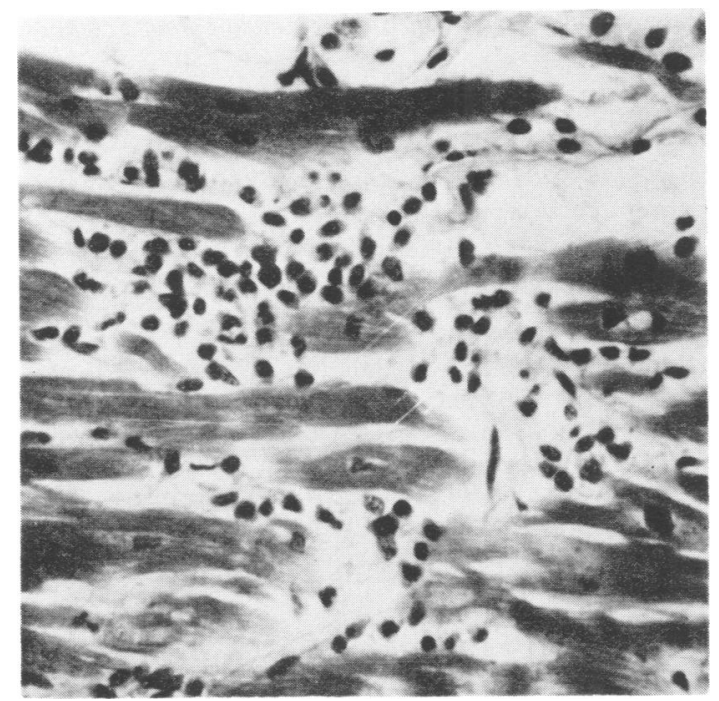

Fig. 4 Necrotic muscle fibre in the heart with interstitial inflammatory cell infiltration.

(Haematoxylin and eosin $\times 100$.)

Hearts from the six control cases in group 2 were examined in a similar way but no abnormality of the muscle fibres was seen.

\section{Discussion}

Raised intracranial pressure has been suggested as a possible cause of the hypothalamic lesions (Crompton 1963) and ECG changes (Jachuck et al., 1975) seen after subarachnoid haemorrhage. However, this study fails to support such an argument for, although in both groups there was pathological evidence of raised intracranial pressure, hypothalamic and myocardial lesions were found only in group 1 patients.

The clinical findings in these patients of a deteriorating level of consciousness, fluctuating blood pressures and pulse rates, and an abnormal ECG, have been associated with high blood levels of catecholamine after subarachnoid haemorrhage (Cruickshank et al., 1974; Neil-Dwyer et al., 1974). These high catecholamine levels have given support to the suggestion of increased sympathetic action after subarachnoid haemorrhage. One feasible explanation of this increased sympathetic drive is an abnormal hypothalamic response induced by spasm of the small vessels supplying the hypothalamus. Ischaemic lesions have been found at necropsy in the hypothalamus of patients who died after a subarachnoid haemorrhage. The action of the hypothalamus is two-fold: one, a direct action on the sympathetic nervous system resulting in increased catecholamine production, and the other through the pituitary adrenal axis leading to high plasma cortisol levels. In addition, corticosteroids are known to have a potentiating action on the vascular effects of catecholamines (Selye, 1970). The effect of this on the heart, it has been argued, is to give rise to myocardial lesions and to ECG changes similar to those seen in subarachnoid haemorrhage.

This study demonstrates the coexistence of hypothalamic and myocardial lesions and adds further evidence to the above hypothesis. In all our cases, the lesions in the hypothalamus were bilateral and diffuse, with the major damage being in the periventricular region.

Although no definite site for sympathetic overactivity can be located in this study, there is evidence to suggest that the area surrounding the paraventricular nucleus may be responsible for such activity, though it is probable that the overall function of the hypothalamus is disturbed.

The type of cardiac myofibrillar degeneration, frequently focal and subendocardial, found in our cases has been well described not only in the hearts of patients who died after a subarachnoid haemorrhage, but also in association with phaeochromocytomas and parenteral catecholamine administration (Reichenbach and Benditt, 1970).

In only one case in this study was there evidence of severe coronary artery occlusive disease but, as the myocardial lesions were patchy and occurred in a variety of sites in the left ventricle, coronary artery insufficiency due to atheroma was not a major factor.

In this preliminary study no cause and effect relationship can yet be established between abnormal hypothalamic action and the myocardial lesions sustained after subarachnoid haemorrhage. However, a case could be made for a controlled double-blind study on the action of prophylactic beta receptor blockade on these hypothalamic and myocardial lesions, and on the mortality of subarachnoid haemorrhage.

\section{References}

Conor, R. C. R. (1969). Myocardial damage secondary to brain lesions. American Heart Journal, 78, 145148.

Crompton, M. R. (1963). Hypothalamic lesions following the rupture of berry aneurysms. Brain, 86, 301314.

Cruickshank, J., Neil-Dwyer, G., and Stott, A. (1974). The possible role of catecholamines, cortico-steroids and potassium in the production of electrocardiographic abnormalities with subarachnoid haemorrhage. British Heart Journal, 36, 697-706. 
Greenhoot, J. H., and Reichenbach, D. D. (1969). Cardiac injury and subarachnoid hemorrhage. A clinical pathological and physiological correlation. Journal of Neurosurgery, 30, 521-531.

Iliynsky, B. V., and Astrakhantseva, S. P. (1967). Changes of ECG in acute disorders of cerebral circulation as compared to the daily excretion of catecholamines and blood electrolytes. Terapeuticheskii Arkhiv (Moskva), 39, 53-57.

Jachuck, S. J., Ramani, P. S., Cleark, F., and Kalbac, R. M. (1975). Electrocardiographic abnormalities associated with raised intracranial pressure. British Medical Journal, 1, 242-244.

Melville, K. I., Blum, B., Shister, H. E., and Silver, M. D. (1963). Cardiac ischemic changes and arrhythmias induced by hypothalamic stimulation. American Journal of Cardiology, 12, 781-791.

Neil-Dwyer, G., Cruickshank, J., Stott, A., and Brice, J. (1974). The urinary catecholamines and plasma cortisol levels in patients with a subarachnoid haemorrhage. Journal of the Neurological Sciences, 22, 375-382.

Reichenbach, D. D., and Benditt, E. P. (1970). Catecholamines and cardiomyopathy. Human Pathology, 1, 125-150.

Selye, H. (1970). The evolution of the stress concept. American Journal of Cardiology, 26, 289-299.

Smith, B. (1963). Cerebral pathology in subarachnoid haemorrhage. Journal of Neurology, Neurosurgery, and Psychiatry, 26, 535-539.

Tomomatsu, T., Veba, Y., Matsumoto, T., Oda, M., Ikoma, T., Kondo, Y., and Ijiti, Y. (1964). Electrocardiographic observations and urinary excretion of catecholamines in cardiovascular disorders. Japanese Circulation Journal, 28, 905-912.

Zavodskaya, I. S., Moreva, E. V., and Sinitsina, T. A. (1972). Morphological and biochemical changes in animal vascular wall after hyperstimulation. Cor et Vasa, 14, 204-212. 